\title{
Sistem Penerangan Bertenga Surya di Bank Sampah Berkah Abadi Kelurahan Limbungan
}

\author{
David Setiawan $* 1$, Masnur Putra Halilintar $^{2}$, Wati Masrul ${ }^{3}$ \\ 12Program Studi Teknik Elektro, Fakultas Teknik, Universitas Lancang Kuning \\ 3Program Studi Arsitektur, Fakultas Teknik, Universitas Lancang Kuning \\ *e-mail: dsetia@unilak.ac.id
}

\begin{abstract}
The Berkah Abadi Waste Bank is a waste bank that is managed independently so there must be a lot to do with its turnover or income. The cost of electricity which is usually used for lighting systems at night is considered quite large with current income declining. This decrease was caused by management activities from waste self-management into a waste bank. When self-management of waste, receipts are received from the cleaning fee for each resident's house. In addition to fees, the collected waste is sorted and the rest is disposed of in a landfill. From the fees and sales of waste segregation, the activities of the waste bank are quite adequate, but with the issuance of the waste management policy through Perwako number 134 of 2018, the eternal blessing garbage bank no longer carries out self-management of community waste but hopes for the waste saved by the community. The lighting system is needed for the safety of the waste bank, where work equipment and machines are needed so that sufficient lighting is needed at night. The problem is, the cost of electricity is quite large and small income is a problem for the manager. The installation of a solar-powered lighting system at the Abadi Berkah Waste Bank is a solution to the problem of high electricity costs. Prior to the installation of the lighting system, the manager received training on solar power generation systems, electrical systems in general and their maintenance. Then assistance is carried out to ensure the manager can install lighting properly and correctly. The evaluation was carried out by analyzing the results of the questionnaires filled out by the training and mentoring participants. Based on the results of the activity, 8 40-watt lamps are not turned on again at night and turn on a powerful lighting system so that electricity costs are cheap.
\end{abstract}

Keywords: Lighting System, Solar Power, Electricity Cost, Waste Bank, Save.

\begin{abstract}
Abstrak
Bank Sampah Berkah Abadi adalah bank sampah yang dikelola secara mandiri sehingga pengeluaran harus diimbangi dengan omset atau pemasukannya. Biaya listrik yang umumnya digunakan untuk sistem penerangan pada malam hari dirasa cukup besar dengan pendapatan saat ini yang menurun. Penurunan ini diakibatkan oleh perubahan kegiatan pengelolaan dari swakelola sampah menjadi bank sampah. Saat swakelola sampah, pendapatan diterima dari uang kebersihan setiap rumah warga. Selain iuran kebersihan, sampah yang diambil dipilah dan sisanya baru dibuang ke tempat pembuangan akhir sampah. Dari iuran dan penjualan pilahan sampah, kegiatan bank sampah cukup memadai namun dengan keluarnya kebijakan pengelolaan sampah melalui perwako nomor 134 tahun 2018 maka bank sampah berkah abadi tidak lagi melakukan swakelola sampah masyarakat namun berharap dari tabungan sampah yang ditabung masyarakat. Sistem penerangan diperlukan untuk keamanan bank sampah, dimana peralatan kerja dan mesin - mesin berpeluang dicuri sehingga diperlukan penerangan yang cukup pada malam hari. Permasalahannya, biaya listrik yang cukup besar dan pemasukan yang kecil menjadi permasalahan bagi pengelola. Kegiatan pemasangan sistem penerangan bertenaga surya di Bank Sampah Berkah Abadi adalah solusi dari permasalahan mahalnya biaya listrik. Sebelum dilaksanakannya pemasangan sistem penerangan, pengelola mendapatkan pelatihan tentang pembangkit sistem tenaga surya, sistem kelistrikan secara umum dan perawatannya. Kemudian dilakukan pendampingan untuk memastikan pengelola dapat memasang sistem penerangan dengan baik dan benar. Evaluasi kegiatan dilakukan dengan menganalisa hasil quisioner yang diisi oleh peserta pelatihan dan pendampingan. Berdasarkan hasil kegiatan, 8 lampu penerangan yang berdaya 40 watt tidak lagi dihidupkan pada malam hari dan digantikan dengan sistem penerangan bertenaga surya sehingga biaya listrik menjadi murah..
\end{abstract}

Kata kunci: Sistem Penerangan, Tenaga Surya, Biaya Listrik, Bank Sampah, Hemat. 


\section{PENDAHULUAN}

Bank Sampah Berkah Abadi berdiri diatas lahan hibah seluas $300 \mathrm{~m} 2$ dan dibangun oleh Dinas PUPR tahun anggaran 2015 dengan luas hanggar $120 \mathrm{~m} 2$ dan bagunan $40 \mathrm{~m} 2$ serta didukung dengan berbagai jenis mesin dan peralatan administrasi baru yang diperoleh dari Program Bank Sampah PT CPI dan Unilak .

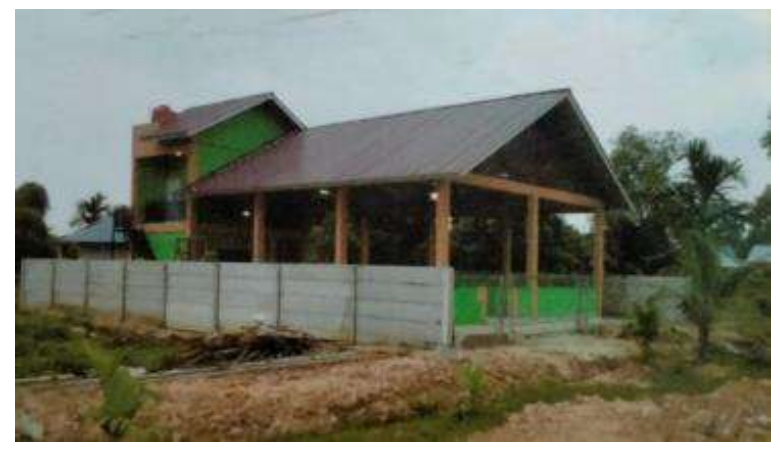

Gambar 1. Tempat Bank Sampah Berkah abadi

Bank Sampah Berkah Abadi memiliki struktur organisasi dimana pengelolaan bank sampah diketuai oleh Pak Ibnu Hajar (sebelumnya ketua RW.09 Kelurahan Limbungan).

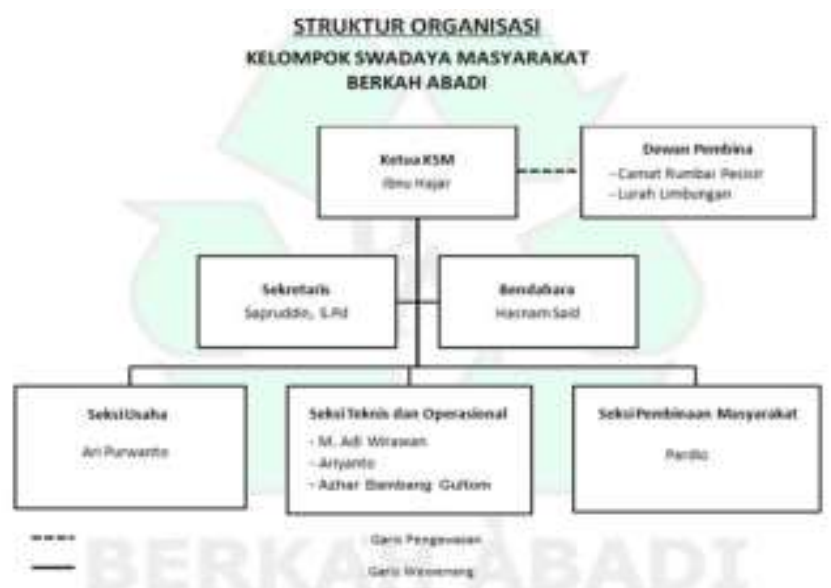

Gambar 2. Struktur Organisasi Bank Sampah Berkah Abadi

Sumber energi listrik untuk mendukung kegiatan pada Bank Sampah Berkah Abadi bersumber dari PLN dan mesin yang berbahan bakar solar. Energi listrik dari PLN umumnya digunakan untuk sistem penerangan sementara mesin-mesin menggunakan diesel berbahan bakar solar. Sistem penerangan yang digunakan terletak pada ruang kerja dan ruang tengah / aula tempat operasi dilaksanakan setiap hari. Seiring meningkatnya biaya listrik akibat tidak adanya subsidi listrik dan penggunaan penerangan yang selalu hidup pada malam hari untuk keamanan aset bank sampah, maka perlu dicarikan solusi agar biaya listrik dapat dihemat serta lampu tetap hidup disaat terjadinya gangguan pada PLN. Tim Pengabdian Unilak memberikan solusi yaitu teknologi tepat guna dimana panel surya digunakan untuk mendapatkan energi listrik gratis dari energi sinar matahari.

Kebutuhan akan sistem penerangan untuk menjaga keamanan aset serta administrasi perkantoran pada bank sampah serta adanya pengeluaran biaya listrik sehingga diperlukan suatu solusi untuk menekan biaya keluar namun operasi tetap berjalan. Solusi yang ditawarkan adalah sistem penerangan menggunakan tenaga matahari atau panel surya 


\section{METODE}

Metode dalam pelaksanaan pengabdian kepada masyarakat yang akan dilakukan menggunakan 3 tahap kegiatan, dimana setiap kegiatan saling berhubungan. Adapun tahapan kegiatan yang dimaksud adalah :

1. Penyuluhan dan Pelatihan
a. Penyuluhan dilakukan untuk memotivasi pengelola dalam hal memanfaatkan energi listrik dalam mendukung kegiatannya
b. Pelatihan tentang cara memasang alat sistem penerangan menggunakan panel surya termasuk perawatannya

2. Memberikan Alat kepada Mitra

a. Panel Surya

b. Charge Controler

c. Batery / Aki serta kebel untuk instalasi ke lampu sebagai sistem pencahayaan

3. Pendampingan dan Evaluasi Hasil

Kegiatan pendampingan dilakukan untuk memantau ketrampilan pengelola dalam mengoperasikan dan merawat sistem pencahayaan menggunakan panel surya serta mengukur ketermanfaatan kegiatan yang dilakukan.

\section{HASIL DAN PEMBAHASAN}

Setelah mempersiapkan peralatan dan bahan pelatihan serta instrumen evaluasi berupa kusioner penilaian kegiatan, pada tanggal 5 april 2021 dilaksankan pelatihan tentang instalasi tenaga surya untuk sistem penerangan di bank sampah Berkah Abadi kelurahan Limbungan.

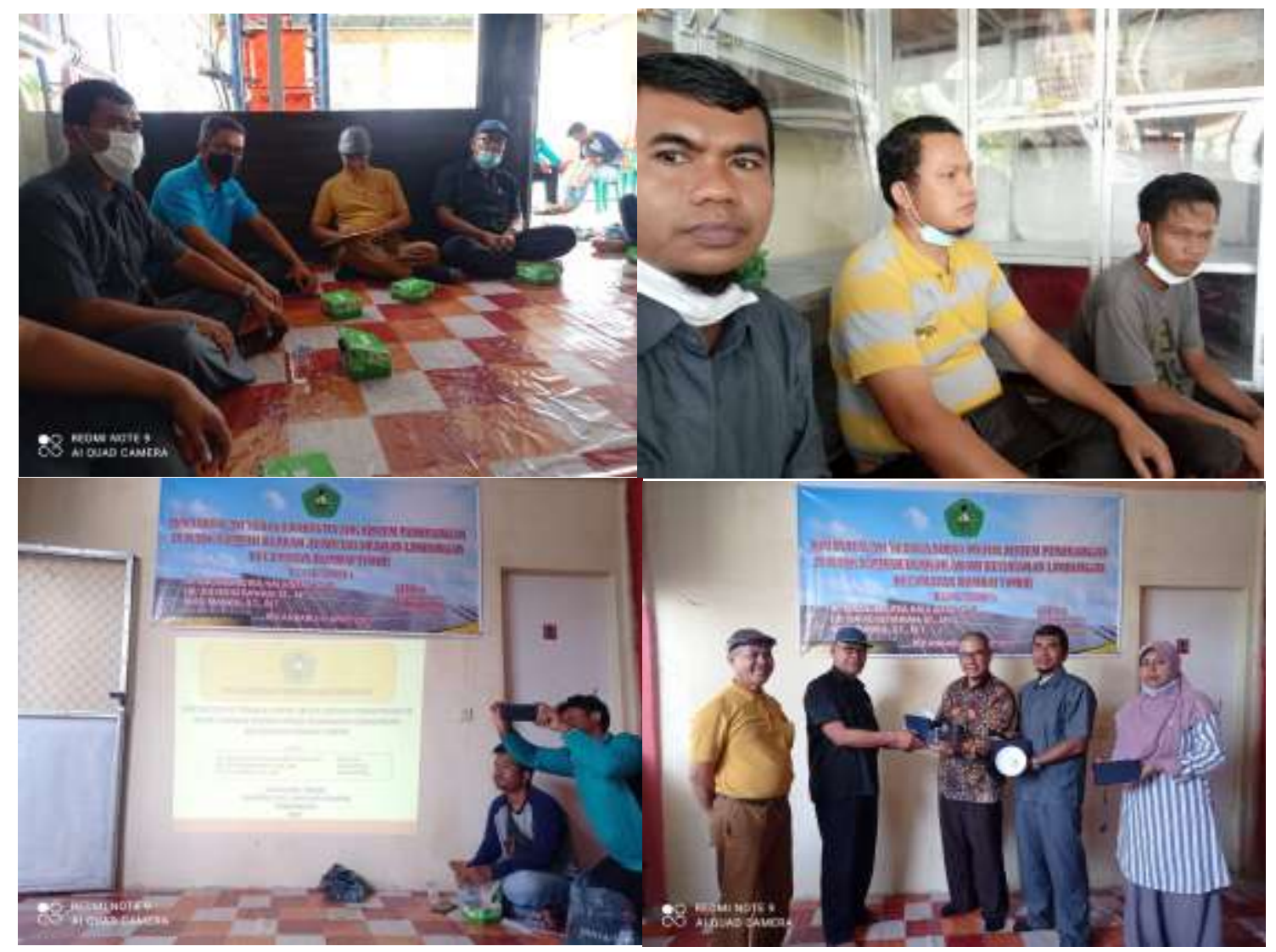

Gambar 3. Pelaksanaan pelatihan dan serah terima Peralatan Sistem Penerangan bertenaga Surya kepada pengelola

Setelah dilaksanakannya pelatihan, tim meberikan pendampingan kepada pengelola atau teknisi yang ditunjuk pengelola untuk memasang sistem penerangan dan panel surya di Bank 
Sampah Berkah Abadi kelurahan Limbungan.

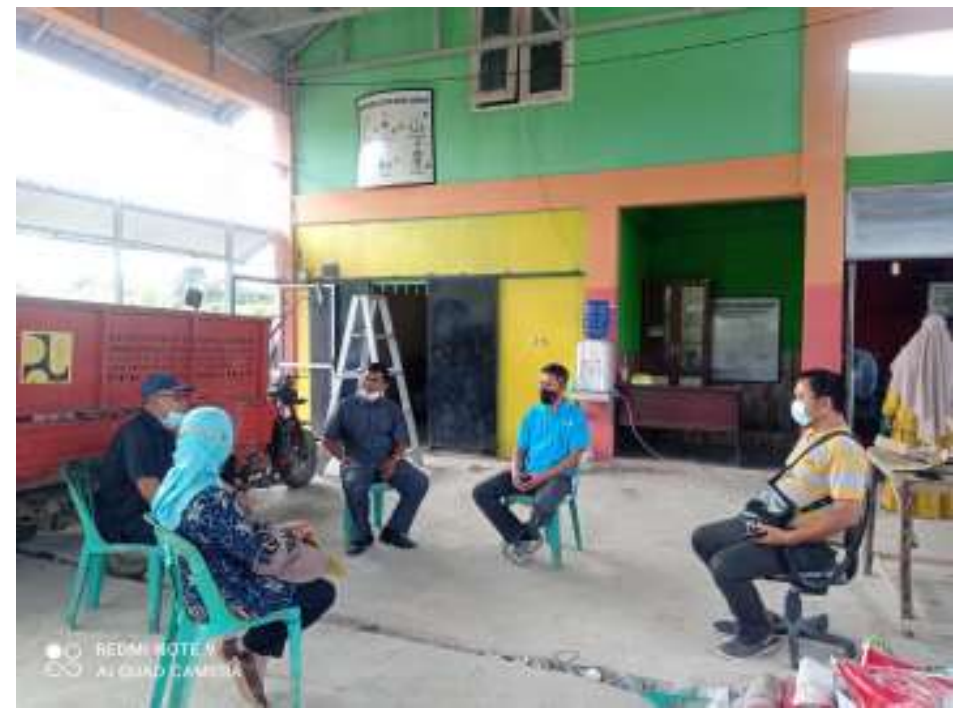

Gambar 4. Pendampingan kepada pengelola / Teknisi yang memasang Sistem Penerangan Bertenaga Surya

Setelah dilakukan pemasangan, sistem penerangan dengan sumber energi tenaga surya telah hidup pada malam hari dan otomatis mati pada saat siang hari atau terang.

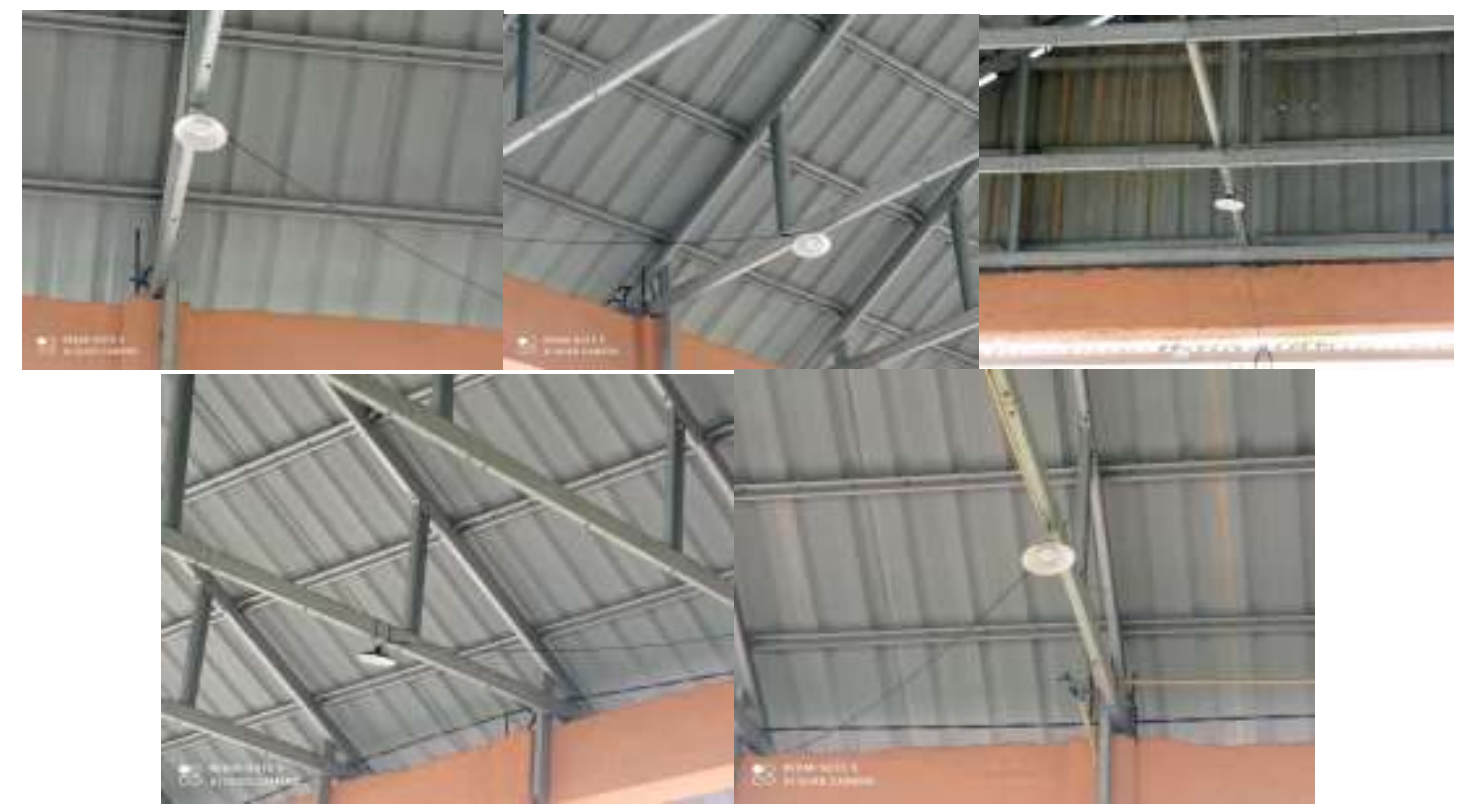

Gambar 4. Sistem penerangan yang telah terpasang

Untuk mengetahui persepsi peserta terhadap pelatihan dan pendampingan yang dilaksanakan, tim mengolah data dan menganalisis menggunakan pendekatan analisis kuantitatif dan deskripsi kualitatif. Analisis data secara kuantitatif adalah persepsi peserta terhadap dampak dan fasilitas kegiatan pengabdian kepada masyarakat pada peserta / mitra dilakukan dengan cara menghitung rata-rata jawaban responden pada skala likert. Jenis skala tersebut digunakan untuk mengetahui distribusi frekuensi responden berdasarkan persepsi secara keseluruhan. Bobot jawaban skala likert menurut Avenzora (2008) disajikan pada Tabel 1. 
Tabel 1 Bobot Jawaban Skala Likert

\begin{tabular}{ll}
\hline Skala Likert & Bobot nilai \\
\hline Sangat setuju & 5 \\
Setuju & 4 \\
Cukup Setuju & 3 \\
Kurang setuju & 2 \\
Tidak setuju & 1 \\
\hline
\end{tabular}

Setelah dibuat skor dari jawaban tersebut, kemudian dibuat skala. Dalam menentukan skala terlebih dahulu dicari nilai intervalnya dengan menggunakan perhitungan sebagai berikut:

$$
\frac{\text { bobot tertinggi }- \text { bobot terendah }}{\text { Jumlah kelas }}=\frac{5-1}{5}=0.80
$$

Setelah nilai interval diketahui, kemudian dibuat skala untuk mengetahui tingkatan persepsi sehingga dapat diketahui letak penilaian responden terhadap setiap unsur. Skala tingkatan persepsi disajikan pada Tabel 3.

Tabel 2 Tingkatan persepsi peserta

\begin{tabular}{ll}
\hline Tingkat persepsi & Interval nilai \\
\hline Sangat tidak baik & $1.00-1.79$ \\
\hline Tidak baik & $1,80-2.59$ \\
\hline Ragu - ragu & $2.60-3.39$ \\
\hline baik & $3.40-4.19$ \\
\hline sangat baik & $4.20-5.00$ \\
\hline
\end{tabular}

Tingkat persepsi dari setiap unsur lalu dideskripsikan sesuai dengan fakta di lapangan. Berdasarkan hasil penilaian terhadap kuisioner yang diberikan dapat diketahui bahwa persepsi peserta terhadap fasilitas kegiatan sebagai berikut :

Tabel 3 Penilaian Peserta Terhadap Fasilitas Kegiatan

\begin{tabular}{|c|c|c|c|c|}
\hline \multirow{2}{*}{ No } & \multirow{2}{*}{ Nama Peserta } & \multicolumn{3}{|c|}{ Repon Peserta } \\
\hline & & A1 & $\mathbf{A 2}$ & A3 \\
\hline 1 & Ibnu Hajar & 3 & 3 & 5 \\
\hline 2 & Galih & 5 & 5 & 5 \\
\hline 3 & Yona Sandy & 5 & 5 & 5 \\
\hline 4 & Subandi & 4 & 4 & 5 \\
\hline 5 & Ashar B. Gultom & 4 & 4 & 4 \\
\hline 6 & Hasnam Said & 4 & 3 & 4 \\
\hline & Rata-rata & 4,2 & 4,0 & 4,7 \\
\hline & Total Rata-r & & & 4,28 \\
\hline
\end{tabular}

Total rata-rata fasilitas kegiatan diantaranya kenyamanan tempat pelatihan, kapasitas tempat pelatihan dan alat bantu pelatihan yang memadai yaitu 4,28, berdasarkan tingkat persepsi peserta pada tabel 2, rata-rata 4,28 dikategorikan sangat baik. 
Tabel 4 Penilaian Peserta Terhadap Materi Pelatihan

\begin{tabular}{|c|c|c|c|c|c|c|}
\hline \multirow{2}{*}{ No } & \multirow{2}{*}{ Nama Peserta } & \multicolumn{5}{|c|}{ Repon Peserta } \\
\hline & & B1 & B2 & B3 & B4 & B5 \\
\hline 1 & Ibnu Hajar & 5 & 3 & 4 & 3 & 5 \\
\hline 2 & Galih & 5 & 5 & 5 & 5 & 5 \\
\hline 3 & Yona Sandy & 5 & 5 & 5 & 5 & 5 \\
\hline 4 & Subandi & 5 & 5 & 5 & 5 & 5 \\
\hline 5 & Ashar B. Gultom & 5 & 5 & 5 & 5 & 5 \\
\hline 6 & Hasnam Said & 4 & 4 & 5 & 4 & 5 \\
\hline & Rata-rata & 4,8 & 4,5 & 4,8 & 4,5 & 5,0 \\
\hline
\end{tabular}

Total rata-rata untuk materi pelatihan yaitu apakah materi sesuai topik, susunan materi yang sistematis, terdapat contoh, materi mudah dipahami dan menarik serta materi meningkatkan pengetahuan dan kemampuan peserta pelatihan adalah 4,73, berdasarkan tingkat persepsi peserta pada tabel 2, rata-rata 4,73 dikategorikan sangat baik.

Tabel 5 Penilaian Peserta Terhadap Instruktur / Pelatih

\begin{tabular}{|c|c|c|c|c|c|}
\hline \multirow{2}{*}{ No } & \multirow{2}{*}{ Nama Peserta } & \multicolumn{4}{|c|}{ Repon Peserta } \\
\hline & & C1 & C2 & C3 & $\mathrm{C4}$ \\
\hline 1 & Ibnu Hajar & 5 & 5 & 4 & 5 \\
\hline 2 & Galih & 5 & 5 & 5 & 5 \\
\hline 3 & Yona Sandy & 5 & 5 & 5 & 5 \\
\hline 4 & Subandi & 5 & 5 & 5 & 5 \\
\hline 5 & Ashar B. Gultom & 4 & 4 & 4 & 4 \\
\hline 6 & Hasnam Said & 3 & 4 & 4 & 4 \\
\hline & Rata-rata & 4,5 & 4,7 & 4,5 & 4,7 \\
\hline \multicolumn{5}{|c|}{ Total Rata-rata } & 4,58 \\
\hline
\end{tabular}

Total rata-rata untuk Penilaian Instruktur yaitu kompetensi, kejelasan dalam penyampaian materi, menciptakan suasana aktif dan komunikatif dan suara / intonasi instruktur adalah 4,58, berdasarkan tingkat persepsi peserta pada tabel 2, rata-rata 4,58 dikategorikan sangat baik.

Tabel 6 Penilaian Peserta Terhadap Manfaat Pelatihan dan Pendampingan

\begin{tabular}{|c|c|c|c|c|}
\hline \multirow{2}{*}{ No } & \multirow{2}{*}{ Nama Peserta } & \multicolumn{3}{|c|}{ Repon Peserta } \\
\hline & & D1 & D2 & D3 \\
\hline 1 & Ibnu Hajar & 5 & 4 & 5 \\
\hline 2 & Galih & 5 & 5 & 5 \\
\hline 3 & Yona Sandy & 5 & 5 & 5 \\
\hline 4 & Subandi & 4 & 4 & 4 \\
\hline 5 & Ashar B. Gultom & 5 & 5 & 5 \\
\hline 6 & Hasnam Said & 5 & 4 & 4 \\
\hline & Rata-rata & 4,8 & 4,5 & 4,7 \\
\hline \multicolumn{3}{|c|}{ Total Rata-rata } & & 4,67 \\
\hline
\end{tabular}


Sedangkan total rata-rata untuk kemanfaatan pelatihan seperti ketermanfaatan pelatihan, pengetahuan peserta menjadi meningkat dan pelatihan serta pendampingan yang diberikan dapat menjadi solusi mitra adalah 4,67 , berdasarkan tingkat persepsi peserta pada tabel 2, rata-rata 4,67 dikategorikan sangat baik.

\section{KESIMPULAN}

Berdasarkan kegiatan dan uraian diatas, penulis dapat menyimpulkan sebagai berikut:

1. Pelaksanaan pelatihan dan pendampingan menghasilkan sistem penerangan dengan memanfaatkan tenaga surya sebagai sumber energinya sehingga biaya penerangan menjadi lebih hemat karena tidak menggunakan listrik dari PLN.

2. Fasilitas kegiatan, materi pelatihan, instruktur yang kompeten serta ketermanfaatan pelatihan berdasarkan tingkat persepsi peserta, seluruhnya dikategorikan sangat baik yang artinya pelatihan dan pendampingan yang diberikan menjadi solusi dari mitra.

3. Mitra merasakan manfaat berupa pengetahuan yang meningkat dan pengalaman langsung memasang sistem penerangan bertenaga surya serta pengelola tidak perlu lagi membayar tagihan listrik untuk penggunaan sistem penerangan pada aula/ruang kerja bank sampah.

\section{UCAPAN TERIMA KASIH}

Ucapan terimakasih kami sampaikan kepada Pimpinan Universitas Lancang Kuning dan Lembaga Penelitian dan Pengabdian kepada Masyarakat yang telah mendanai kegiatan pelatihan dan pendampingan ini melalui APBU universitas Lancang Kuning tahun 2021.

\section{DAFTAR PUSTAKA}

Affan Bachri, 2015, Analisis Efisiensi Pemakaian Daya Listrik Di Universitas Islam Lamongan, Jurnal Teknika Vol. 7 No.1, ISSN No. 2085-0859

David Setiawan, Hamzah Eteruddin, Latifa Siswati, 2020, Sistem Pembangkit Listrik Tenaga Surya Untuk Tanaman Hidroponik, Jurnal Teknik Volume 14, No. 2 Tahun 2020

Indrakoesoema Koes, Kiswanto, Muhammad Taufiq, 2013, Kajian Penghematan Energi Listrik Dengan Pemasangan Inverter Pada Motor Fan Menara Pendingin Rgs - Gas, Seminar Nasional VIII SDM Teknologi Nuklir, ISSN : 1978-0176

Itmi Hidayat Kurniawan, Latiful Hayat, 2014, Perancangan Dan Implementasi Alat Ukur Tegangan,Arus Dan Frekuensi Listrik Arus Bolak-Balik Satu Fasa Berbasis Personal Computer, Techno Jurnal Vol.15 No.1, hal. 21-31 ISSN 1410 - 8607

Panggih Sudarmono, Deendarlianto, Adhika Widyaparaga, 2018, Energy efficiency effect on the public street lighting by using LED light replacement and kwh-meter installation at DKI Jakarta Province, Indonesia, Journal of Physics: Conf. Series 1022(2018) 012021 doi:10.1088/1742-6596/1022/1/012021

Zubaili Isfarizky, Fardian, Alfatirta Mufti, 2017, Bangun Sistem Kontrol Pemakaian Listrik Secara Multi Channel Berbasis Arduino (Studi Kasus Kantor LBH Banda Aceh), JurnalTeknik Elektro,Fakultas Teknik Universitas Syiah Kualam Vol.02-02 hal: 30-35 e-ISSN: 2252-7036 